12. Terkulov, V.I. (2010). Kontsept v performativnom lingvalnom byitii cheloveka [The concept in the performative lingual existence of a person]. Visnyk Kyivskoho natsionalnoho linhvistychnoho universytetu. Seriia Filolohiia [Bulletin of Kyiv National Linguistic University. Philology series], 14 (1), 178-188 [in Russian].

13. Zalevskaya, A.A. (2003). Yazyikovoe soznanie: voprosyi teorii [Linguistic consciousness: issues of theory]. Voprosyi psiholingvistiki [Issues of psycholinguistics], 1, 30-35 [in Russian].

DOI https://doi.org/10.30525/978-9934-26-039-1-51

\title{
COVID-19 В ПОЛІСЕМІОТИЧНИХ ТЕКСТАХ АНГЛОМОВНОЇ СОЦІАЛЬНОЇ РЕКЛАМИ
}

\section{Ткачук-Мірошниченко О. Є.}

кандидат філологічних наук, доцент кафедри мови та стилістики Інституту журналістики

Киівського національного університету імені Тараса Шевченка м. Київ, Украӥна

Рік 2020 увійде в історію як рік безпрецедентних викликів для людства, які вимагали швидких та ефективних антикризових рішень. Жодна сфера життєдіяльності не уникла впливу COVID-19. Потреба в інформуванні про нову повсякденну реальність та заохочення до дотримання нових правил, як то добровільна самоізоляція, соціальна дистанція, гігієна тощо, сприяли створенню соціальних рекламних текстів з теми COVID-19.

В умовах епідемії COVID-19 у 2020 році англомовні соціальні рекламні тексти були мотивовані глобальною стратегією - спонукання до швидких змін старої та дотримання нової моделі соціальної поведінки через стратегію інформування про новий вірус та його наслідки.

Проте інформаційне завзяття 3МІ з експлуатацією страхів (fear sells/ fear-mongering) та нагнітанням панічних настроїв (panic mongering), підкріплених статистикою смертей та візуальним компонентом (так званий «раndemic porn») [6] переросло в інфодемію (від англійського infodemic: a tsunami of information, a rapid and far-reaching spread of both accurate and inaccurate information about something, such as a disease. As facts, rumors and fears mix and disperse, it becomes difficult to learn essential 
information about an issue) [MWD] та інформаційне ожиріння (від англійського infobesity (=information + obesity): condition of continually consuming large amounts of information, especially when this has a negative effect on a person's well-being and ability to concentrate) [MMD].

В результаті негативного інформаційного перевантаження градус тривожності (pandemic anxiety), емоційного вигоряння (pandemic fatigue) та психічного оніміння (psychic numbing) в суспільстві зріс. Як наслідок, недовіра до державних та приватних джерел інформації та заперечення існування COVID-19 та ігнорування нових правил посилились.

Аби подолати інформаційну байдужість, створити позитивний вплив на психоемоційну сферу людини та полегшити досягнення комунікативної мети та прагматичного впливу, адресанти соціальних рекламних текстів на тему Covid-19 звернулись до полісеміотичних гумористичних текстів.

Полісеміотичний, креолізований [4] текст $є$ поєднанням засобів вербальної і невербальної комунікації в єдиному текстовому просторі; лінгвовізуальний феномен, текст, у якому вербальний та невербальний компоненти утворюють одне візуальне, структурне, смислове та функціонуюче ціле, що забезпечує його комплексний прагматичний вплив на адресата [1]. Невербальний компонент полісеміотичного рекламного тексту представлений візуальним каналом (малюнок, фотографія, символічні зображення, художні ілюстрації тощо) та знаками поліграфічної семіотики (підкреслення, вид та розмір шрифтів тощо) [3].

Адресант рекламного тексту використовує гумор на всіх рівнях: вербальному та невербальному [9]. В основі механізму створення гумористичності лежать протиріччя «когнітивний контраст», «відчутний абсурд», «видима безглуздість», «відхилення від норми» [2].

Для аналізу гумористичності візуального невербального компоненту в полісеміотичному тексті соціальної реклами на тему Covid-19 була обрана українська англомовна кампанія \#ArtOfQuarantine, яка за два тижні стала вірусною та була доставлена 130+ мільйонам користувачам. Завдяки своїй креативності вона була висвітлена в світових журналах та ЗМI. Ця кампанія відбулась в рамках глобальної ініціативи \#ArtOfQuarantine \#FlattenTheCurve \#COVID-19 \#MKIП \#WHO \#UN [5]. Досліджувані рекламні тексти, які об'єднані тезою «дотримання нових правил поведінки в умовах COVID-19 - це мистецтво», побудовані на використанні образів впізнаваних творів образотворчого мистецтва в гумористичному візуальному контексті які «подорожують» у часі, комунікуючи правила гігієни та поведінки під час COVID-19 та 
спонукаючи до їх дотримання. Кожний рекламний текст містить невербальний і вербальний компоненти, які, поєднуючись в одному текстовому просторі, утворюють полісеміотичний рекламний текст. Наприклад, якщо на оригінальній картині Леонардо да Вінчі «Пані 3 горностаєм» ми бачимо тварину, тоді в рекламі замість тварини пані тримає в руках сучасні упаковки з продуктами. Вербальний компонент представлений заголовком MAKE SUPPLIES (при цьому застосовано капіталізацію та курсив) та текстом Making supplies lets you remain home for a longer time and minimize the potential risks of infection. В іншому прикладі впізнаємо картину «Орфей і Еврідіка» Ф. Лейтона, на якій Орфей «одягнув» рукавички та захисну маску. Вербальний компонент структурно ідентичний попередньому - заголовок KEEP THE DISTANCE (поєднання капіталізації та курсиву) та текст Being in public places, keep the distance of 2 meters to other people. На інших рекламах можна побачити Наполеона із жовтим рюкзаком служби доставки їжі із надписом Food, Мадонну, яка молиться у рукавичках, молодого чоловіка у червоному, який миє руки рідким милом та Ісуса Христа, який «самоізолювався» у масці під час Тайної вечері. При цьому композиційна структура полісеміотичних текстів соціальної рекламної кампанії зберігається.

Отже, залучаючи до комунікативної ситуації невербальні візуальні компоненти, адресант посилює атрактивність та комунікативний ефект рекламного тексту. Рекламні тексти соціальної тематики допускають ефективне використання полісеміотичних текстів 3 гумористичним візуальним компонентом, в основі якого лежить абсурд. В умовах існування комунікативних бар'єрів гумор виконує важливу психоемоційну функцію. Ефективність рекламної кампанії підвищується завдяки наскрізній композиційно-смисловій структурі полісеміотичного рекламного тексту.

\section{Література:}

1. Анисимова Е. Е. Паралингвистика и текст (к проблеме креолизованных и гибридных текстов). Вопросы языкознания. 1992. № 1. C. 71-79.

2. Кошелев А. Д. О структуре комического (анекдот, каламбур, шарж, пародия, шутка, комическая история). Логический анализ языка: Языковые механизмы комизма / под ред. Н. Д. Арутюновой. Москва, 2007. C. 278.

3. Рыбакова О. Н. Дискурсивные, коммуникативно-прагматические и семиотические характеристики англоязычной печатной рекламы: 
автореф. дис. ... канд.филол.наук: спец. 10.02.04 «Германские языки»; ИГУ, 1999. 22 с.

4. Сорокин Ю. А., Тарасов Е. Ф. Креолизованные тексты и их коммуникативная функция. Оптимизация речевого воздействия. Москва, 1990. C. $180-181$.

5. ArtOfQuarantine. URL: https://madmap.com.ua/projects/art-ofquarantine (дата звернення 16.02.2021).

6. Berezov A. Coronavirus and the Ethics of 'Pandemic Porn'. URL: https://www.acsh.org/news/2020/05/28/coronavirus-and-ethics-pandemic-porn-14818 (дата звернення 19.02.2021).

7. MMD. URL: https:// www.macmillandictionary.com/buzzword/ entries/infobesity.html\#:-:text (дата звернення 18.02.2021).

8. MWD. URL: https://www.merriem-webster.com/words-at-play/wordswere-watching-infodemic-meaning (дата звернення 18.02.2021).

9. Yurieva E. V. Verbal and Non-verbal Techniques of Creating the Comic in Creolized Texts of Social Advertisement. Izv. Saratov Univ. (N. S.), Ser. Philology. Journalism, 2017. Vol. 17. iss. 1, P. 24-28 (in Russian). DOI: 10.18500/1819-7663-2017-17-1-24-28.

DOI https://doi.org/10.30525/978-9934-26-039-1-52

\title{
LINGUOSTYLISTIC PECULIARITIES OF POETIC DISCOURSE
}

\author{
Chendey N. V. \\ Ph. D. in Philology, \\ Associate Professor at the English Philology Department \\ Uzhhorod National University \\ Uzhhorod, Ukraine
}

Poetic discourse is defined as linguistic and mental space created by the author and his/her reader by means of a poetic text that combines three aspects: linguistic, communicative and cognitive [1, p. 6].

The linguistic aspect is embodied in a poetic text itself (hereinafter - PT) by thoroughly selected language means that can be perceived sensitively.

The communicative aspect is revealed in a dialogue between the author and reader of a PT in which a poetic function of language prevails and defines the implication of a vast range of linguostylistic devices.

The cognitive aspect deals with the verbalization of artistic concepts. Discourse concepts configuration is defined as a totality of key concepts that 202 